\title{
A Comparative Study on the Impact of Traditional and Inclusive Teaching Strategies on Students' Learning
}

\section{Asma Naureen*}

Department of Education, Faculty of Social Sciences, International Islamic University, Islamabad, Pakistan

*Corrosponding author’s Email: i_kayani@yahoo.com

Peer-review under responsibility of $4^{\text {th }}$ Asia International Conference 2018 editorial board (http://www.utm.my/asia/our-team/) (C) 2018 Published by Readers Insight Publisher, lat 306 Savoy Residencia, Block 3 F11/1,44000 Islamabad. Pakistan, info@ readersinsight.net This is an open access article under the CC BY-NC-ND license (http://creativecommons.org/licenses/by-nc-nd/4.0/). 


\section{Research High Iights}

This research paper was focused at analyzing the impact of traditional and inclusive teaching strategies on the learning of students of class II, in inclusive setting. In inclusive teaching all the students are included in learning process without any discrimination. (Ainscow et al, 2006) "Inclusive learning and teaching is to engage students in learning that is meaningful, relevant and accessible to all. It embraces a view of the individual and individual difference as the source of diversity that can enrich the lives and learning of others". (Hockings, 2010)

The study was experimental in nature in which traditional and inclusive instructional strategies were compared. The study proposed three hypotheses and the results of the study indicated that the students of experimental group and control group were almost equal before conducting the experiment. The result of post-test shows that the students of experimental group who were taught in inclusive teaching setting had shown comparatively better results than the students placed in control group who were taught in a traditional way. So, achievement level of students of experimental group was better than that of the students of control group which proved that inclusion in teaching was more effective than the traditional teaching setting. Ambrose et al, (2010) also recommended inclusive teaching strategies and said it is important that the pedagogical strategies we employ in the classroom reflect an understanding the psyche and social needs of the students.

\section{Research Objectives}

The main objectives of the study were:

1. To find the impact of inclusion on the learning of students with special needs.

2. To find the impact of inclusion on the learning of students without special needs.

\section{Significance of the Study}

This experimental study is very significant in different ways; on one hand it would give awareness to the people about inclusive education as even many of the teachers do not know about inclusion. On the other hand, it would enable the community members to adopt the positive attitude towards those children who are suffering from some disorders or disabilities or different from other students. This study would provide guidance to the teachers and parents for helping students with and without special needs. It would also help the teachers 


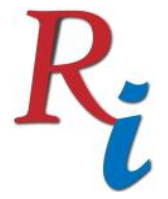

Asia Proceedings of Social Sciences

(APSS)

www.readersinsight.net/APSS

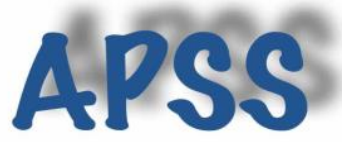

and administrators to look and analyze their teaching and make necessary changes in their educational strategies. Key principles are valuing diversity, entitlement, dignity, individual needs, planning, collective responsibility, professional development, and equal opportunities." (Darlington, 2003)

According to UNESCO, 2005 it is the duty of the state as well as of the society to involve all the students in learning process and no one feels excluded. In the National Report on the Development of Education, 2008 the emphasis was given on inclusive education with the objective to support Education For All (EFA), with special emphasis on eradicating the obstacles to all excluded: girls and women, the disabled, ethnic/linguistic minorities, nomads, and many others to participate and learn in regular schools so this study would enhance the efforts of government in creating the positive attitude among the educators in specific and public in general.

\section{Methodology}

The study was experimental in nature in which traditional method of imparting instruction was compared with inclusive instructional strategies. The procedure of the study was that two groups of students had been taken and tested before and after teaching. Pre-test, post-test equivalent design was used in this research study. In this design, pre-test was administered before the application of the experimental and control treatments and post-test was administered at the end of the treatment period. Students studying in three sections of class II constitute the population of the study. They are 83 students who are studying in three different sections. Their ages ranged from 7 to 9 years. Sample was taken from the school named F.G. Junior Model School, G-7/3-1, Islamabad. Sample size consists of 56 students, twenty-eight students were placed in experimental group and same number of students was in the control group. Both the groups were representative of inclusion, in which there were students from religious/linguistic minorities, slow learners, having low vision or articulation, hyper-actives, etc. Pre-test was used before the treatment started to equate the groups. Treatment of planned inclusive instructional techniques was given to experimental group while control group was taught by ordinary traditional method. The duration of it was two forty days. When the treatment period over, an instructor made post-test was conducted to measure the achievement of the students in the subject of English. First four lessons were taken from the text book for class II. To determine the impact of inclusive instructional strategies on students' learning in inclusive setting and traditional teaching in inclusive setting, the significance of difference between the scores of experimental and control groups 


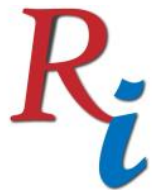

\section{Asia Proceedings of Social Sciences}

(APSS)

www.readersinsight.net/APSS

at 0.05 level was tested by applying t-test and analysis was made. It was shown by analysis of data that both the groups (experimental and control) in the beginning of the experiment were approximately equal.

\section{Results}

The results of post-test have shown that inclusive instructional strategies were more effective than that of traditional method of teaching students at primary level as experimental group scored significantly higher than the control group. The result of the study reflected that inclusive instructional strategies were more effective than traditional method of teaching.

\section{Findings}

The following findings emerged because of the analysis of data.

a) It was found that the mean scores of control group was not found to be almost equal on pre-test and post-test.

b) It was found that there was significant difference between mean scores on pre-test and post-test of experimental group after being treated by inclusive teaching strategies.

c) It was found that the mean score of experimental group and that of the control group was not statistically significant at 0.05 levels. Hence, both the groups were found to be almost equal on pre-test.

d) It was found mean score of experimental group was more than that of control group after being treated by inclusive teaching strategies. 


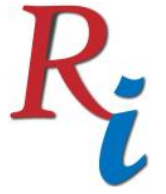

\section{Asia Proceedings of Social Sciences}

(APSS)

www.readersinsight.net/APSS

\section{References}

Ambrose, S. A., Bridges, M.W., DiPietro, M. \& Lovett, M.C. (2010). How learning works: Seven research-based principles for smart teaching. San Francisco, JosseyBass.

Ainscow M., Booth T. and Dyson, A. with Farrell, P., Frankham, J., Gallannaugh, F., Howes, A. and Smith, R. (2006). Improving Schools, Developing Inclusion. Abingdon, Oxon: Routledge.

Darlington, C. (2003). The Challenges of Effective Inclusion, Times Educational Supplement, USA.

Hockings.C, (2010). Inclusive learning and teaching in higher education: a synthesis of research

UNESCO (2005). Children out of school: Measuring exclusion from primary education. Montreal: UNESCO Institute for Statistics. 